\title{
The Analysis of Housewife Behavior in Dealing with Family Needs Because of Price Increase
}

\author{
Yuni Astuti Christina Catur Widayati* \\ Faculty of Economics and Business, Department of Management, Universitas Mercu Buana Jakarta
}

\begin{abstract}
The declining purchasing power of the people due to the increasing prices of goods and services is felt with varying degrees of resilience for families with various income levels (Yudha, 2015). The problem that is happening now is that housewife plays the double role besides as mother who has to settle household affairs also have to work to increase family income so that family needs remain fulfilled even though prices continue to increase. Besides that, income is also an average of Rp 4 million / month. Although already above the UMR with increasing prices, the income earned is now felt less. The type of research is quantitative by taking samples saturated as many as 36 housewives who work with not leave the house area RW 01 Joglo Village, Kembangan Sub-District West Jakarta. The research time is 6 months starting from the beginning of the academic year of February to July 2018. The data collection method in this research uses survey method with the research instrument using closed questionnaire. Data analysis method using Partial Least Square (PLS). Based on the results of data analysis can be concluded that the increase in price has no significant effect on family needs, family needs have a significant positive effect on the behavior of housewives, price increases have no significant effect on the behavior of housewives, price increases have a significant positive effect on the behavior of mothers -housing households without variables mediating family needs. Suggestions for the housewives need to diversify the various needs of the family so that purchases for the needs of everyday families are not affected by rising prices in addition to the social sense can still be maintained.
\end{abstract}

Kata kunci: Perilaku, kebutuhan keluarga, kenaikan harga

DOI: $10.7176 / \mathrm{JMCR} / 56-04$

Publication date:May $31^{\text {st }} 2019$

\section{INTRODUCTION}

The high price increase affects consumer purchasing decisions on daily necessities, especially beef. Some consumers will take action whether to reduce the consumption of beef or move to other products, such as chicken or mutton that the price is still affordable. To meet the daily needs of some mothers took the initiative to make food, traditional cakes, then sold to increase family income. The current phenomenon is that housewife plays a double role besides as mother who has to take care of household affairs also have to work to increase income, so that family needs remain fulfilled even though the price keeps increasing. Besides that, income is also an average of Rp 4 million / month. Although already above the UMR with increasing prices, the income earned is now felt less. The effect of price changes on the number of goods demanded more complex because it involves the substitution effect and income effects. The substitution effect is the effect of price changes that cause consumers to replace from goods that are relatively expensive with goods whose prices are relatively cheaper. While the effect of income is the effect of price changes that cause consumer real income changes, then cause changes in the number of goods requested. So based on the theory earlier then the mothers by themselves change the consumption of food every day, as well as the quantity bought in order to survive. The result of research Kusdiyanto (2014) explains that tofu and fermented soybean cake is a substitute side dish for fish, but know fermented soybean cake, not complement / cannot replace fish.

The results of opposite research are produced by Alfauzan et al (2015) research, ie there is a real influence between mandarin orange prices and the number of requests. If the price of mandarin oranges increases then demand remains even increased. Consumers of mandarin oranges do not change to Siam oranges that are cheaper.

On the other hand, Deacon and Firebaugh (1981) argue that families have coping strategies when there is a change in income that affects their spending allocations. Family values and goals will be affected if there is a change in income level. The family will make adjustments because basically the implementation of family financial planning with a relatively low level of income is limited by time and money resources.

The results of research Rahmawati (1999) describes other efforts made by the family, among others, is to change the quality of food and non-food consumption, by changing the brand of products purchased, from the category of expensive to medium or cheap. In July 2006 (2005) various efforts were made by each family to maintain prosperity in the face of increasing fuel prices by reducing expenditures, increasing incomes, either by increasing work hours (overtime), developing productive businesses, releasing or selling assets, borrowing or borrowing at formal non-formal institutions or stalls / kiosks, and utilize savings owned.

Based on the above research phenomena, it is interesting to examine the importance of analyzing the behavior of housewives in the face of family needs due to price increases. 


\section{CONCEPTUAL FRAMEWORK AND HYPOTHESIS DEVELOPMENT}

\section{a. The relationship between price increase and housewife behavior}

According to Hattas (2011), the factors that influence consumption patterns are: (1) the level of public income, (2) consumer appetite, (3) the price of goods, (4) the level of community education, (5) the number of families and (6) ) Environment. The family strategy in facing the price increase among others with:

a) Changes in frequency and quality of food and non-food expenditure.

The pattern of family expenditure is strongly influenced by the income they receive. The increase in the price of needs has changed the level of real income families, also affect the pattern of expenditure both for food consumption and non-food.

b) Changes in the quality of food and non-food products.

One of the family strategies in handling declining purchasing power, which is the negative impact of rising prices of basic commodities and services, is by making savings. Saving is not only done by pressing the quality but also in quantity, so it will affect the frequency of use or purchase. One of the biggest challenges in managing finances is limiting spending.

c) Changes in the quality of food and non-food consumption

One of the family strategies in handling the declining purchasing power, which is the negative impact of the rise of various goods and services by means of savings. Savings are not only done by pressing quantity of quantity purchased only but also in quality, thus affecting the frequency of use or purchase. For example, for rice consumption, families make changes to quality, meaning that families make changes by buying rice at prices cheaper than those commonly consumed before the price increase of basic commodities.

The relationship between the two variables is reinforced by the results of Saliem and Ariningsih (2005) research which found that there is a change of consumption and expenditure of staple food and lead to noodles/flour. Based on the above explanation then the hypothesis to be built is:

H1: $_{1}$ Price increases have a positive effect on the behavior of housewives

\section{b. The relationship between price increase to family needs}

Model Hierarchy of Needs according to Abraham Maslow, the need is the basis of the formation of consumer behavior. Needs are defined as the perception of the difference between the desired state and the actual situation sufficient to activate the decision process in consuming (Engel, Blackwell, Miniard, 1994). The recognition of needs depends essentially on how many discrepancies exist between the actual state (ie, the current consumer) and the desired state (ie, the situation that consumers want) (Engel, Blackwell, Miniard, 1994). If the consumer's needs are not met, he will show a disappointing behavior. Conversely, if the needs are met, consumers will exhibit happy behavior as a manifestation of their satisfaction (Mangkunegara, 2002: 5). The point discussed in the need is to see its influence on habits or traditions in their behavior. Cultural differences, even the same culture with different individuals, may exhibit different behaviors. However, in response to the desire for basic needs, there are similarities (Seeley, 1988). According to Abraham Maslow in Kinicki (2008), the need consists of 5 components: the physiological needs, the need for a sense of security, the need to feel belonging, the need for self-esteem, and the need for self-actualization. The relationship between the two variables is reinforced by the results of Chalid (2010) study which found that the average proportion of food expenditure is quite good in Riau per capita area of 55.77\% per month in 2005. Although the price increase, the proportion of food purchases for the family is still quite good. Based on the above explanation then the hypothesis to be built is:

$\mathbf{H}_{2}$ : Price increases have a positive effect on family needs

\section{c. The relationship between family needs and housewife behavior}

According to Benjamin Bloom (1908), there are three levels of behavior, namely 1). Knowledge (knowledge), is the result of human sensing of the object through the senses it has, 2). Attitude (attitude), is a person's closed response to a particular stimulus or object that already involves factors of opinion and emotion in question, 3). Action or practice, guided practice is to do something by using guidance. While the practice of the mechanism is to do things automatically. The process of behavior formation is influenced by several factors derived from within the individual itself, these factors include 1). Perceptions, experiences generated through the sense of sight, hearing, smell, etc. 2). Motivation, defined as the impulse to act in achieving a certain goal, the result of these drives and movements is manifested in the form of behavior, 3). Emotion, the man in attaining maturity in all aspects related to heredity and emotions will evolve according to the law of development, therefore the behavior that arises because of emotion is innate behavior, 4). Learning, according to Barelson (1964), learning is a behavioral change resulting from past behavior. The relationship between the two variables was reinforced by the results of the study (Oktaviasari, 2016) which found that the survival strategy undertaken was to diversify the work. With the increasing need for families, it is necessary to double the role of housewives, besides as housewives, she also works to increase the family's income to meet family needs. Based on the above explanation then the hypothesis to be built is: 
$\mathbf{H}_{3}$ : Family needs have a positive effect on the behavior of housewife

\section{d. The Role of Mediation of Family Needs in Influence of Price Increase on Housewife Behavior}

According to the Maslow Needs Hierarchy Theory, diverse human needs can be grouped into 5 groups, according to the order of importance are as follows: 1). Physiological Needs (Physiological Needs), 2). Need For Self-Security, 3). The need for love and belonging (Need for love and Belongingness), 4). Need for selfesteem, 5). Need for Self-Actualization. Price increases greatly affect the needs of families, then affect the behavior of housewives in the family's needs, such as selling food-cookies, washing clothes and so on. Srimadeni (2014) in her study found that the life of a family that does not have a job still has difficulty in meeting daily needs, especially with the price needs that always increase so that the wife helps the husband in meeting the needs of life by selling. Based on the above explanation then the hypothesis to be built is: $\mathrm{H}_{4}$ : Family needs play a role in mediating the influence of price increases on the behavior of housewives

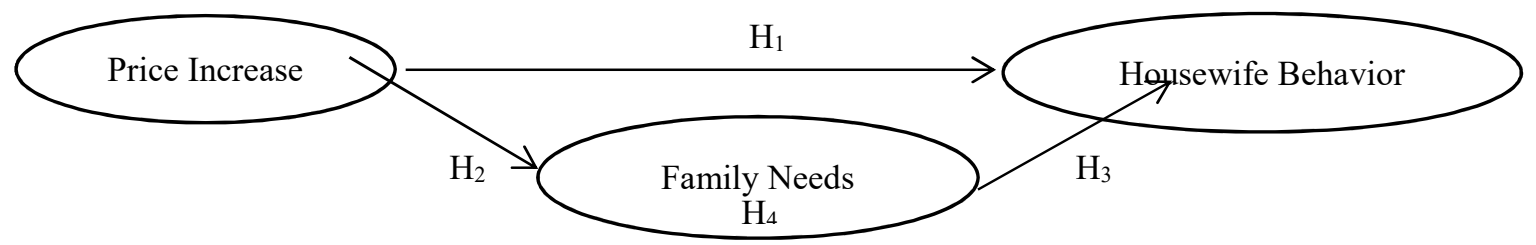

Figure 1. Conceptual Framework

\section{METDHODOLOGY}

This study is a causal associative study because it analyzes family needs in mediating the effect of price increases on the behavior of housewives. This research was conducted from February 2018 until August 2018. The research method used is survey method. Using questionnaires to respondents to collect data in measuring variable price increases, and family needs in the formation of the behavior of housewives.

Measurement of variable price increases using Adam Smith measurements (1779), family needs using Abraham Maslow measurement (1934) and housewife behavior using measurement scale Benjamin Bloom (1908). Measurement scale using the Likert scale with categories ranging from (1) strongly disagree to scale (5) strongly agree.

The population in this research are the housewife who has the double role in RW 01 Joglo Village, Kembangan Sub-district, some 36 people, which is data analysis method using Partial Least Square (PLS). Measurement of research variables is shown in Appendix 1.

\section{DATA ANALYSIS AND DISCUSSION}

\section{a. Respondent Characteristics}

Characteristics of respondents can be seen in Appendix 2. By gender, the number of respondents all housewives a number of 36 people. Based on the age of respondents most over 41 years ( 21 people), most recent education graduated high school (20 people), per month opinion of most between Rp 1-3 million (16 people).

\section{b. Partial Least Square}

1) Evaluation of Measurement Model (Outer Model)

\section{a) Validi ty test}

Validity testing is done in two ways namely the convergent validity and discriminant validity. According to Chin in Ghozali and Latan (2015), an indicator is said to have good convergent validity if the loading factor value is greater than 0.7. However, in the scale research, loading factor 0,50-0,60 is still acceptable. The test results are shown in Figure 2. 


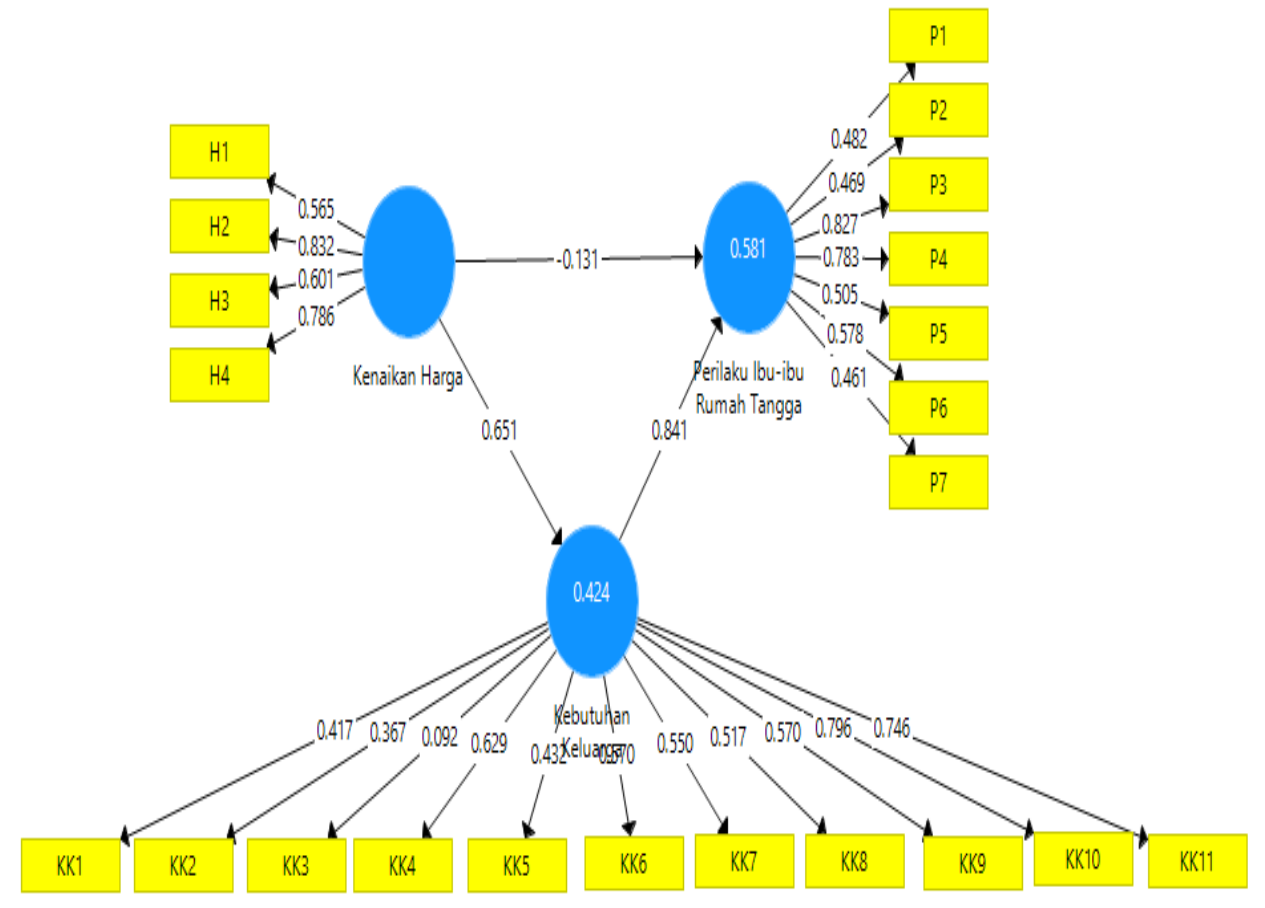

Figure 2. Test Result Convergent Validity

Source: Data Analysis Result, 2018

The results of the PLS algorithm indicate that there are some indicators that have a loading factor value of less than 0.5 for family needs variables: KK1 (0.417), KK2 $(0.367)$, KK3 (0.092), KK5 $(0.432)$, as well as for mother- mother: P1 (0.482), P2 (0.469), and P7 (0.461) then said the indicator is invalid then removed from the model. The table can be seen in Table 1 below.

Table 1. Test Result Convergent Validity

\begin{tabular}{cccc}
\hline Variables & Indicators & Outer Loading & Information \\
\hline \multirow{2}{*}{ Price Increase $\left(\mathrm{X}_{1}\right)$} & $\mathrm{H} 1$ & 0,565 & Valid \\
& $\mathrm{H} 2$ & 0.832 & Valid \\
& $\mathrm{H} 3$ & 0,601 & Valid \\
& $\mathrm{H} 4$ & 0,786 & Valid \\
Family Needs $\left(\mathrm{X}_{2}\right)$ & $\mathrm{KK} 2$ & 0,417 & Invalid \\
& KK3 & 0,367 & Invalid \\
Variables & KK4 & 0,092 & Invalid \\
& Indicators & 0,629 & Valid \\
& KK5 & Outer Loading & Information \\
& KK6 & 0,432 & Invalid \\
Family Needs $\left(\mathrm{X}_{2}\right)$ & KK7 & 0,570 & Valid \\
& KK8 & 0.550 & Valid \\
& KK9 & 0.517 & Valid \\
& KK10 & 0.570 & Valid \\
& KK11 & 0.796 & Valid \\
& P1 & 0.746 & Valid \\
& P2 & 0,482 & Invalid \\
& P3 & 0,469 & Invalid \\
P4 & 0,827 & Valid \\
& P5 & 0,783 & Valid \\
& P6 & 0,505 & Valid \\
& P7 & 0,578 & Valid \\
& & 0,461 & Invalid
\end{tabular}

Source: PLS output (2018)

After invalid indicators are removed, then a recount is made. Here are the outputs of the omission of indicators and recounts. 


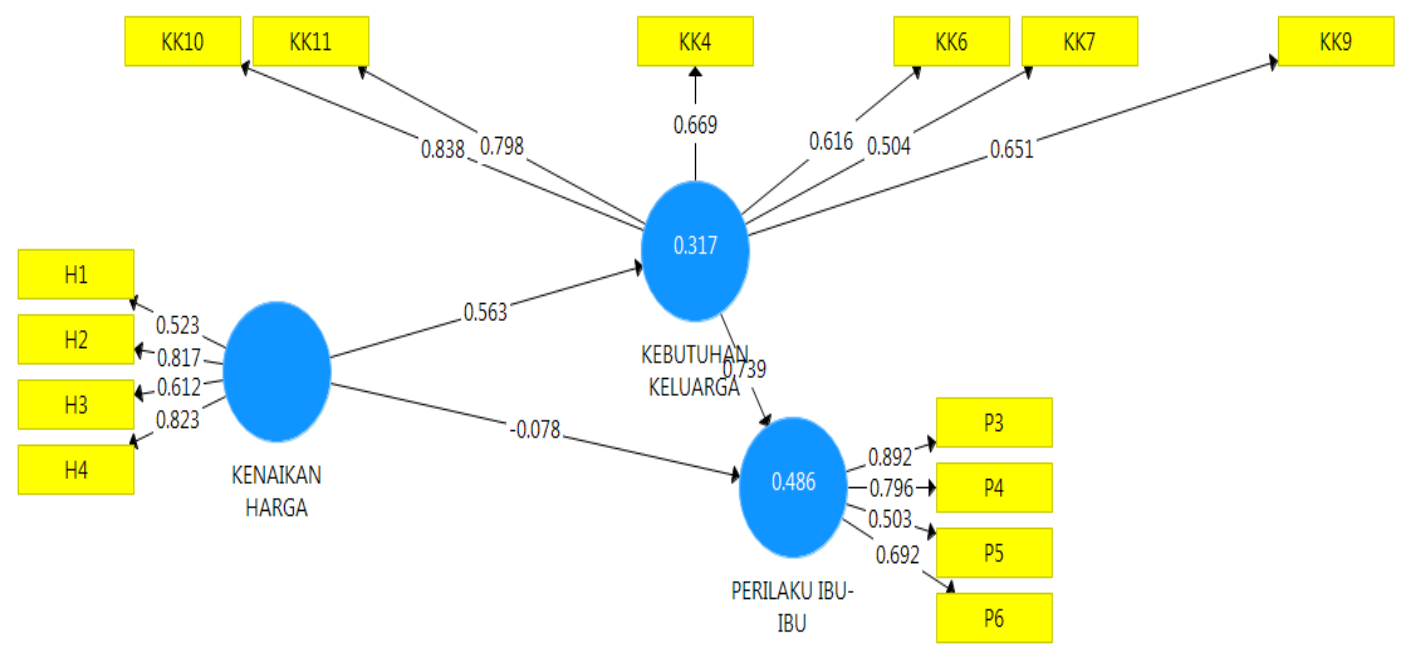

Figure 3. Test Result Convergent Validity

Source: Primary Data, processed using Smart PLS series 3, 2018

Figure 3 above shows the existence of indicators for the three variables, namely price increases, family needs and the behavior of mothers, is valid all. This indicates that the indicators are the correct tools as the questionnaires and the resulting data can be tested further.

Table 2 below is an explanation of valid indicators with values above the 0.5 factor loading, i.e. for $\mathrm{H}_{1}(0,523)$, $\mathrm{H}_{2}(0.817), \mathrm{H}_{3}(0.612)$ and $\mathrm{H}_{4}(0.823)$ variable variables, for the family KK4 family variable $(0.669), \mathrm{KK} 6(0.616)$, KK7 (0.504), KK9 (0.651), KK10 (0.838) and KK11 (0.798), for the behavioral variables of P3 mothers $(0.892)$, P4 (0.796), P5 (0,503 and P6 (0.692). The result of modification of convergent validity test in Figure 2 and Table 2 , can be seen that all indicators have met the convergent validity because it has factor loading value above 0.50 .

Table 2. Test Result Convergent Validity (modification)

\begin{tabular}{cccc}
\hline Variables & Indicators & Outer Loading & Information \\
\hline Price Increase $\left(\mathrm{X}_{1}\right)$ & H1 & 0,523 & Valid \\
& H2 & 0,817 & Valid \\
& H3 & 0,612 & Valid \\
Family Needs $\left(\mathrm{X}_{2}\right)$ & H4 & 0,823 & Valid \\
& KK4 & 0,669 & Valid \\
& KK6 & 0,616 & Valid \\
& KK7 & 0,504 & Valid \\
& KK9 & 0,651 & Valid \\
& KK10 & 0,838 & Valid \\
Housewife Behavior & KK11 & 0,798 & Valid \\
(Y ) & P3 & 0,892 & Valid \\
& P4 & 0,796 & Valid \\
& P5 & 0,503 & Valid \\
& P6 & 0,692 & Valid \\
\hline
\end{tabular}

Source: Results of data analysis Smart PLS 3, (2018)

\section{Discriminant Validity}

Discriminant validity test, a reflective indicator can be seen on cross loading between indicators with its construct. An indicator is valid if it has the highest loading factor to the target construct compared to the loading factor to another construct. Thus, latent constructs predict the indicators on their blocks are better than those in other blocks.

The following table shows the results of the Discriminant Validity Test (Cross Loading) indicating that the price increase with the $\mathrm{H}_{1}$ indicator $(0,523), \mathrm{H}_{2}(0.817), \mathrm{H}_{3}(0.612)$ and $\mathrm{H}_{4}(0.823)$., Is higher than the correlation among other constructs, then the correlation of the construct of family needs with KK4 indicator $(0,669)$, KK6 $(0,616), \operatorname{KK} 7(0,504), \operatorname{KK} 9(0,651), \operatorname{KK} 10(0,838)$ and $\operatorname{KK} 11(0,798)$ higher value compared with correlation among other constructs. Furthermore, the correlation of mother's behavioral construct with P3 indicator $(0,892)$, P4 $(0,796)$, P5 $(0,503)$ and P6 $(0,692)$ higher than correlation among other constructs. Thus it can be concluded that all measurement variables have good discriminant validity. 
Table 3. Discriminant Test Result Validity (Cross Loading)

\begin{tabular}{cccc}
\hline Indicators & Prie Increase $(\mathrm{H})$ & Family Needs $(\mathrm{KK})$ & Housewife Behavior ( P ) \\
\hline H1 & $\mathbf{0 , 5 2 3}$ & 0291 & 0,177 \\
H2 & $\mathbf{0 , 8 1 7}$ & 0,492 & 0,202 \\
H3 & $\mathbf{0 , 6 1 2}$ & 0,273 & 0,084 \\
H4 & $\mathbf{0 , 8 4 9}$ & 0,471 & 0,397 \\
KK4 & 0,404 & $\mathbf{0 , 6 6 9}$ & 0,405 \\
KK6 & 0,524 & $\mathbf{0 , 6 1 6}$ & 0,424 \\
KK7 & 0,518 & $\mathbf{0 , 5 0 4}$ & 0,192 \\
KK9 & 0,159 & $\mathbf{0 , 6 5 1}$ & 0,463 \\
KK10 & 0,401 & $\mathbf{0 , 8 3 8}$ & 0,654 \\
KK11 & 0,313 & $\mathbf{0 , 7 9 8}$ & 0,629 \\
P3 & 0,356 & 0,659 & $\mathbf{0 , 8 9 2}$ \\
P4 & 0,295 & 0,527 & $\mathbf{0 , 7 9 6}$ \\
P5 & 0,141 & 0,414 & $\mathbf{0 , 5 0 3}$ \\
P6 & 0,136 & 0,378 & $\mathbf{0 , 6 9 2}$ \\
\hline
\end{tabular}

Source: Primary Data, processed using Smart PLS series 3, 2018

b) Reliability Test

Reliability test is done with Composite Reliability and Cronbach's Alpha Testing composite reliability and Cronbach's alpha aims to test the reliability of the instrument in a research model or measure internal consistency and its value must be above 0.7. If all values of latent variables have composite reliability or Cronbach Alpha> 0.7. This means that Constructs have good reliability or questionnaires used as tools in research have been reliable or consistent.

In Table 4 below, it can be seen that each variable that is the price increase, family needs and behavior of mothers have value of Composite Reliability $>0.70$, meaning that the construct has high reliability or questionnaire used as tool in this research has been reliable or consistent.

Table 4. Test Results Composite Reliability and Cronbach Alpha

\begin{tabular}{lcccc}
\hline \multicolumn{1}{c}{ Variables } & Composite Reliability & Information & Cornbrash's Alpha & Information \\
\hline Family Needs & 0,840 & Reliable & 0,770 & High Reliable \\
Price Increase & 0,793 & Reliable & 0,657 & Medium Reliable \\
Houswife Behavior & 0,819 & Reliable & 0,698 & Medium Reliable \\
\hline
\end{tabular}

Source: Primary Data, processed using Smart PLS series 3, 2018

While the value of Cronbach's Alpha for latent variables Family needs value $>0.7$, reliable high, while for latent variables Price increases and Mother Behavior including reliable moderate. The assessment according to Guilford in Suherman (2003) uses the degree of reliability in Table 5 as follows:

Table 5. Degree of Reliability According to Guilford

\begin{tabular}{ccl}
\hline No. & Score & \multicolumn{1}{c}{ Information } \\
\hline 1 & $0,90-1,00$ & The degree of reliability is very high \\
2 & $0,70-0,90$ & The degree of reliability is high \\
3 & $0,40-0,70$ & The degree of reliability is medium \\
4 & $0,20-0,40$ & The degree of reliability is low \\
5 & $0,00-0,20$ & The degree of reliability is very low
\end{tabular}

Source: Guilford in Suherman, 2003

The results of this study were assessed with the degree of reliability according to Guilford, resulting in all the values of the latent variables have a value of composite reliability between $0.793-0.840$, means that the construct has a high degree of reliability, while Cronbach Alpha between 0.657 - 0.770 has moderate to high reliability. This means that the construct has a moderate to high degree of reliability or a questionnaire that is used as a medium to a good research tool.

\section{2) Evaluation of Structural Model (Inner Model)}

a) Goodness of Fit Model Test

Untuk menilai uji ketepatan model dengan melihat nilai R-square dan R-square adjusted. Pada Tabel 6 ditunjukkan bahwa nilai R-square dan R-square adjusted mempunyai nilai yang rendah kurang dari 0,5 berarti model memiliki ketepatan yang rendah. 
Table 6. Goodness of Fit Model Test

\begin{tabular}{lll}
\hline Endogenous Variables & R Square & Adjusted R-Square \\
\hline Family Needs & 0,317 & 0,297 \\
Houswewife Behavior & 0,486 & 0,455 \\
\hline Source: Primary data is processed using Smart PLS, 2018 Endogenous Variables
\end{tabular}

Source: Primary data is processed using Smart PLS, 2018 Endogenous Variables

The structural model indicates that the model of the family needs and the behavior of the mothers can be said to be weak positive because it has a value less than 0.5 or less than $50 \%$. The influence of family needs variables is influenced by the price increase of 0.297 or $29.7 \%$, as well as the variable behavior of mothers influenced by price increases and family needs of 0.455 or $45.5 \%$, while $54.5 \%$ influenced by variables other than family needs and price increases.

b) Hypothesis Testing (Line Coefficient Estimation)

See the significance of the hypothesis by looking at the value of the parameter coefficient and the significance value of T-statistics on the algorithm bootstrapping report. To know significant or not significant seen from $\mathrm{T}$ table at alpha $5 \%(0,05)=1,96$, then T-table compared with T-count (T-statistic).

Table 7. Hypothesis Testing Results

\begin{tabular}{|c|c|c|c|c|c|c|c|}
\hline Variables & & & $\begin{array}{l}\text { Original } \\
\text { sample }\end{array}$ & $\begin{array}{l}\text { Standard } \\
\text { deviation }\end{array}$ & $\begin{array}{l}\text { T- } \\
\text { stat }\end{array}$ & $\begin{array}{l}\mathrm{P}- \\
\text { value }\end{array}$ & Information \\
\hline \multicolumn{8}{|c|}{ Testing results involve mediators } \\
\hline Family needs & $\rightarrow$ & Housewife & 0,739 & 0,188 & 3,919 & 0,000 & Significant \\
\hline Behavior & & & 0,563 & 0,349 & 1,614 & 0,107 & Insignificant \\
\hline Price Increase $\rightarrow$ & Famil & Needs & $-0,078$ & 0,180 & 0,436 & 0,663 & Insignificant \\
\hline $\begin{array}{l}\text { Price increase } \\
\text { behavior }\end{array}$ & $\rightarrow$ & Housewife & & & & & \\
\hline \multicolumn{8}{|c|}{ Testing results without involving mediators } \\
\hline Price increase $\rightarrow$ & Hous & fe behavior & 0,467 & 0,228 & 2.046 & 0,041 & significant \\
\hline
\end{tabular}

Source: PLS output (2018)

Table 7 describes the results of hypothesis testing, which if Tstatistik $>1,96$ and P-value $<0,05$ then significant, hypothesis accepted, vice versa.

1) Family needs have a significant positive effect on the behavior of housewife. This is indicated by a T-statistic value: $3.919>$ of T-table: 1.96 at the 0.05 level. Beside that also by looking at P-value equal to $0.000<0,05$ so that the result is positive significant, meaning if family need increase then the behavior of mothers also increase.

2) Price increases have no significant effect on family needs. This is indicated by a T-statistic value of $1.614<$ of Tables: 1.96 at the 0.05 level. In addition, by looking at P-value of $0.107>0.05$ so that the results are not significant.

3) Price increases have no significant effect on the behavior of housewives. This is indicated by a T-statistic value of $0.436<$ from Tables: 1.96 at the 0.05 level. In addition, by looking at P-value of $0.663>0.05$ so that the results are not significant

4) Price increases have a significant effect on the behavior of mothers without any variation in the family needs mediation. This is indicated by a T-statistic value of $2.046>$ of T table: 1.96 at the 0.05 level. And see the value of P-value of $0.041<0.05$. The results are also shown in Figure 3 and Figure 4 below.

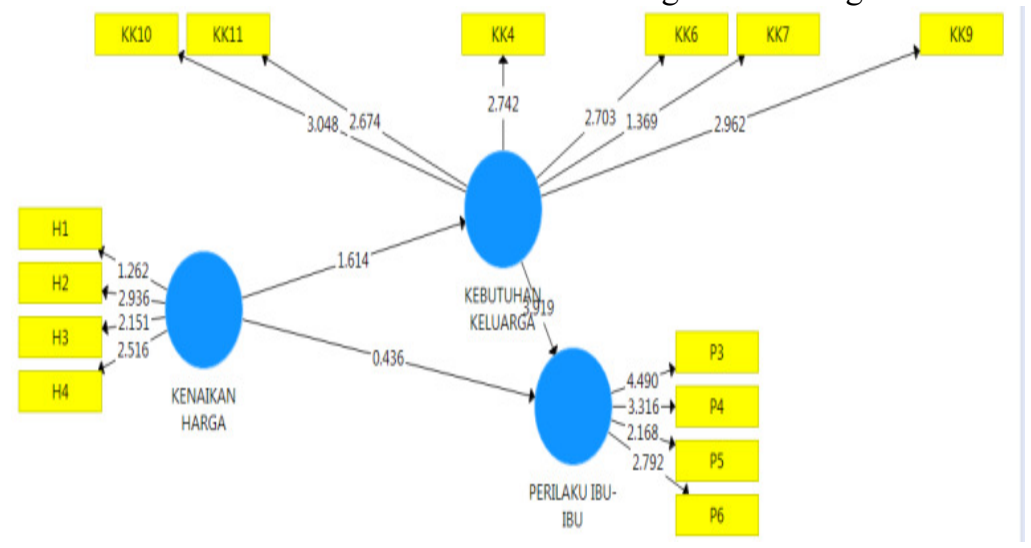

Figure 3. Hypothesis Test Result

Source: Primary Data is processed with Smart OLS 3.0, 2018 


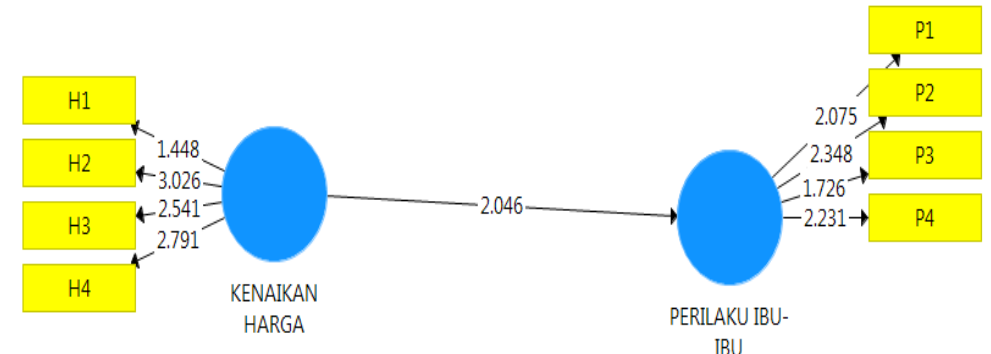

Figure 4. Results of Hypothesis Testing without Mediation Variables

Source: Primary Data processed with Smart PLS 3.0 (2018)

\section{Discussions}

\section{The influence of price increase to houewife behavior}

Based on the hypothesis test, showed the result that the price increase had an insignificant effect on the behavior of housewife. This indicates that the price increase does not affect the behavior of mothers especially in terms of purchasing vegetables, fruits and side dishes for every day. The result of this hypothesis contradicts Frandika's (2015) study that the increase in beef prices to consumer behavior varies with buyers in fixed quantities before and after price increases, reducing the number of purchases or switching to beef consumption. This can be seen from the result of $\mathrm{R}$ square adjusted is weak which is $45,5 \%$, which where housewife's behavior is influenced by price increase equal to $45,5 \%$, while $55,5 \%$ is influenced by variable besides price increase. The results of this study can be explained Theory of planned behavior by Ajzen (Lee \& Kotler, 2011), the target individual is likely to adopt a behavior if the individual has a positive attitude. The positive attitude in question is the behavior of housewives are generally calm in the face of rising prices, can adjust, do not have to work, because work is a hobby.

\section{The influence of price increase to family needs}

Based on the hypothesis test shows that the price increase has no significant effect on family needs. This result is in contrast to the results of Sulindrina's (2015) study which states that the impact of fuel price hikes which is always followed by price increases is very influential on income and consumption expenditure of the poor. In this study, family needs are influenced by the price increase of only $29.7 \%$ so the influence is weak, while $70.3 \%$ of family needs is influenced in addition to price increases. The results of this study can be explained by Maslow's theory by Abraham Maslow, in which man has five levels of life that will always strive to be fulfilled throughout his lifetime. Five levels that can distinguish every human being from the side of the welfare of his life. Considering the respondents are people who earn less than Rp 5 million / month, then the thought is the basic needs first, the physiological needs (clothing, food), have not thought about the needs of the board/house because the income is not enough.

\section{The influence of family needs to housewife behavior}

Based on the hypothesis test, shows the result that family needs have a positive and significant effect on the behavior of housewife. The results of this hypothesis are reinforced by the results of the Shah and Hidir (2004) study that found that female workers have taken part in supplementing family income by working without leaving the role of the wife in the family, from the results of his work to meet the shortcomings or needs of the family perceived lack. Significant positive influence can be explained that the increasing needs of the family are also increasing the behavior of housewives in terms of sufficient or help the needs of the family, for example from managing the food menu to seek income for his family. The results of this study are also reinforced by Setyawati (2011) who found that the contribution of women from the culinary trade installs around the beach is large enough to contribute to the family income is quite large. These results are supported by Role Theory by Goffman (Paul B. Horton and Chester, L, Hunt, 1987), everyone has a number of statuses and is expected to fill according to that status. Job-related roles will give rise to personality changes, thereby reinforcing the mutual influence of people on work and from work on people. Ibu Nurdin is a housewife has 2 types of roles, first as a mother who takes care of all the needs of his family members, the second role earning a living to meet the needs of his family.

\section{Family Needs Role to Mediate Influence of Price Increase Against Behavior of Housewives}

In analyzing the effect of mediation variables, this study used an approach done by Baron and Kenny (1986). Both states that the position of mediation variables in the model can serve as a complete mediation or partial mediation variable.

Baron and Kenny (1986) and Solimun et al (2017) describe the requirements of partial mediation effects if they meet: 1). In the analysis by entering the mediation variable, the path coefficient of exogenous variable influence to the mediation variable and then the path coefficient of the influence of the mediation variable on the endogenous variable must be significant, 2). In the analysis by entering the mediation variable, the path coefficient of exogenous variable effect directly to the endogenous variable is significant. 3). In the analysis by excluding the 
mediation variables, the path coefficient of the exogenous variable effect directly to the endogenous variable is significant, with a greater degree of significance than in the analysis by including the mediation variables.

The results of hypothesis testing by including and without including family variable as mediation variable in the influence of price increase on the housewife's behavior are presented in Figures 3, 4 and 5. Price increases have no significant effect on family needs (line a), family needs are influential positive and significant effect on the behavior of housewives (line b), the direct influence of price increase on the behavior of housewives by involving the variable of family requirement get the significant result (line c). While the direct influence of price increases on the behavior of housewives without involving family needs variables to get significant results (d), with the coefficient value of the larger path. This means that hypothesis 4 is accepted, that family needs are able to mediate the effect of a price increase on the behavior of housewives in partial.

A. As a Mediation Variable

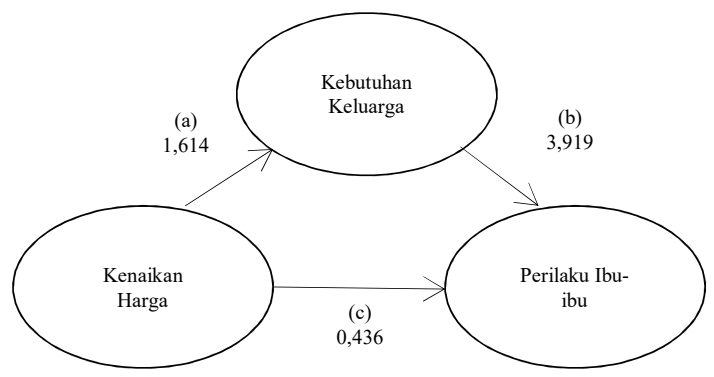

B. Not As Mediation Variable

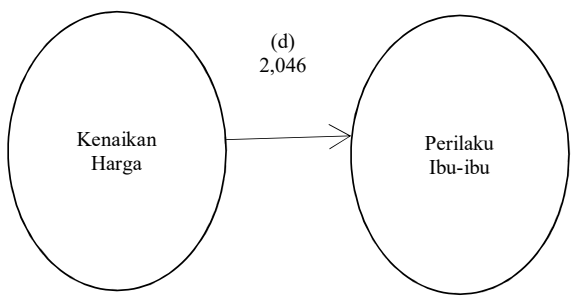

Figure 5. Family Needs Testing Results

\section{CONCLUSION AND SUGGESTION}

\section{a. Conclusion}

Based on the results and previous discussion, it can be concluded that the price increase has no significant effect on the needs of families, family needs have a significant positive effect on the behavior of housewives, price increases have no significant effect on the behavior of housewives, price increases have a significant positive effect on the behavior of housewives without variable mediation needs of the family.

\section{b. Suggestion}

Based on the discussion and conclusion can be recommended for the housewife needs to diversify the various needs of the family so that purchases for the needs of everyday families are not affected by rising prices in addition to the social sense can still be maintained.

\section{REFERENCES}

Alfauzan, F, Subekti, E and Awami, S.N. (2015). "Analysis of Factors Affecting Consumer Behavior Against Fruit Purchase Improvement Decision Pasar Johar Semarang (Case Study of Fuji and Mandarin Orange Fruits)". Mediagro Journal, 11 (1), 35 - 46

Astini, R and Tafiprios, $\mathrm{T}$ (2017). The Application of Three Orientation ( Market, Technology and Entrepreneurship Orientation) and Global Mindset as Efforts to Increase The Growth and Export Performance : Evidence from Micro, Small and Medium Sizes Industries of Teak Furniture in Java Island. Journal of Economic \& Management Perspectives, Publisher : International Economic Society, 11(1), 1731 1742

Bungin, Burhan (2001). Social Research Methodology (Quantitative and Qualitative Formats). Airlangga University Press. Surabaya.

BPS, (2015). Profile of Poverty Sumatera Utara. CPM. North Sumatra.

CPM. (2015). The indicator of People's Welfare. Jakarta. CPM.

Chalid, N. (2010). “Consumption Expenditure RT in Riau Region”. Journal of Economics, 18 (1), 28-40

Deacon, RE., and FM. Firebaugh. (1988). Family Resource Management: Principles and Application. Boston: Alliyn and Bacon Inc.

Dhewanto, W, (2015). "Estimated Annual Inflation: Cause Factors and The Impact on Community Life". Journal of Technology Management. Access date December 14, 2015

Frandika, A.R. (2015). "Impact of Beef Price Behavior on Behavior Consumer". Home Journal, 4 (2), 1-12

Friedman. (1998). Family Nursing, Theory and Practice. Third Edition. California: Appleton \& Lange

Ghozali, I and Latan, H. (2014). Partial Least Squares. Concepts, Techniques, and Applications using Smart PLS 3.0 for Empirical Research (Issue 2). Agency Publisher Diponegoro University.

Gomes, F.C (2010). Human Resource Management. Yogyakarta. Andi Offset

Guhardja S., Puspitawati H., Hartoyo, Martianto DH. (1993). Resource Management Family. Bogor Agricultural 
University, GMSK Department Faculty of Agriculture.

Hamilton, P. (1983). Talcot Parsons. Faculty of Social Sciences, The Open University Milton Keynes.Chisester: Ellis Horword Limited

Jane C. Oblenburger and Hellen A Moore. (1996). Sociology of Women. Jakarta, Rineka Cipta

Kartini, Kartono. (1985). The Role of the Family Guides the Child. Jakarta. Rajawali Press.

Kusdiyanto. (2014). Analysis of Consumer Behavior Against Fish Demand in Surakarta City. National Seminar and Call for Paper. Research methods and organization studies, 102-108

Megawangi, R. (1999). Leaving Different? New Viewpoint on Relations Gender.Jakarta: Mizan Pustaka.

Nurhayati, M (2018). The Effect of Several Demographic Factors On Entreprenurial Intention. Journal of Resources Development and Management. Publisher IISTE, 50, 47 - 55

Oktaviasari, K. (2016). "The strategy of Fulfillment of Economic Needs of Bengkulu Fisherman's Fishery Community in Dealing with the Poor (Case Study of Coastal Coastal Fishermen of Bengkulu City)". Thesis. The University of Bengkulu. Bengkulu.

Rahmawati, Y. et.al. (1999). Analysis of Changes in Food and Non-Food Consumption in Poor Families in Rural and Urban in the Economic Crisis. Media Nutrition \& Family. Thn. XXIII: 2. December 1999.

Rakhmat. J. (2003). Communication Psychology. Youth Rosdakarya. Bandung

Sayogyo, P. (1986). The Role of Women in Households and Communities in Rural Areas Java. Jakarta: Gramedia.

Saliem, H.P, and Ariningsih, E. (2005). Changes in Consumption and Household Expenditure in Rural Areas: Susenas Data Analysis 1999-2005. Center for Socio-Economic Analysis Agricultural Policy - Bogor. 19-37.

Sari, E, and Dwiarti, R. (2018). "Abraham Maslow's Hierarchy Approach to Work Achievement The employee of PT Madubaru (PG Madukismo Yogyakarta)”. Journal of Behavior and Strategy Business, 6 (1), 58 - 77.

Schiffman, Leon and Leslie Lazar Kanuk, (2007). Consumer Behavior, over language Drs Zoelkifli Kasip, PT Index. Jakarta.

Syah, A and Hidir, A. (2004). "The Role of Working Moms In Increasing Family Income". Journal of Social Analysis, 1-15

Solimun, Fernandes, A.A.R, and Nurjanah. (2017). Statistical Method of Multivariate Structural Equation Modeling (SEM) Approach WarpPLS. Poor. UB Press Publishers. Brawijaya University.

Srimadeni. (2014). "Strategy of Poor Family In Fulfilling Life Needs". Final Journal Article S1. Sociology Education Studies Program STKIP PGRI West Sumatra Padang.

Sudjana, N \& Rivai, A (2003). Teaching Technology. New Light. Bandung

Sugiyono. (2010). Qualitative Quantitative Research Methods and $R \& D$. Alfabeta. Bandung.

Suharyadi and Purwanto, (2004). Statistics for Modern Economics and Finance. Volume 2. Salemba Four. Jakarta.

Sulindrina, A. (2015). Impact of Increase in Fuel Price (BBM) on Expenditure of Poor People in Bunulrejo Blimbing Urban Village. Article

Sumardjan, S. (1998). The interaction between Family and Household Members

Seminar on Filling National Family Day 1993 and Welcoming the Day

International Family 1994. Date 21-22 September 1994. Bogor: Institute Bogor Agriculture. Department of Community Nutrition and Family Resources

www.republika.co.id.2015.Low Inflation Due to Community Purchasing Power Decreased.

Republika Daily.02 September 2015.

http://health.kompas.com. 2015. Increase in Food Prices Can Trigger Malnutrition. Compass. April 9, 2015.

Haryfa, Pratama, (2013). teorikonsumsi dan tabungan franco modigliani (https://haryfapratama.wordpress.com/2013/03/29/15-3-teori-konsumsi-dan-tabungan-dari-francomodigliani-2/)

Pakar Lampung, (2010). Faktor utama Kenaikan Harga Sembako

(http://pakar-lampung.blogspot.co.id/2010/07/faktor-utama-penyebab-harga-sembako.html)

Anam, (2012), Dampak Kenaikan Harga Sembako Dan Solusinya

(http://anam-spot.blogspot.co.id/2012/03/sembako.html)

http://ilmuekonomi123.blogspot.co.id/2016/05/pengaruh-kenaikan-harga-sembako.html 